for lactation is $2.1 \mathrm{~g} \mathrm{~K} / \mathrm{kg}$ milk. Like in other ruminants, the coefficient of absorption could amount to $90 \%$.

Due to the high $\mathrm{K}$-content of common goat diets, there are few $\mathrm{K}$-deficiencies in the practice. However, the sometimes massive K-oversupply and its possible negative effects on the metabolism of $\mathrm{Mg}, \mathrm{Na}$, I, Vitamin A, etc. represents a bigger problem. Therefore, the influence of high $\mathrm{K}$ contents and of different $\mathrm{K}: \mathrm{Na}$ ratios in the diet on $\mathrm{Mg}$ - and $\mathrm{Na}$-metabolism of the goat were studied in a balance trial.

A hay-concentrate diet with varying $\mathrm{K}$ - and $\mathrm{Na}$-contents was given to $3 \times 5$ lactating Saanen goats : Treatment $\mathrm{A}: 17.7 \mathrm{~g} \mathrm{~K}$ and $0.6 \mathrm{~g} \mathrm{Na} / \mathrm{kg} \mathrm{DM}$ (normal $\mathrm{K}$ - and $\mathrm{Na}$-supply, $\mathrm{K}: \mathrm{Na}=29.1$ ) ; treatment $\mathrm{B}: 30 \mathrm{~g} \mathrm{~K}$ and $0.7 \mathrm{~g} \mathrm{Na} / \mathrm{Kg} \mathrm{DM}$ (high $\mathrm{K}$ - and normal $\mathrm{Na}$-supply, $\mathrm{K}: \mathrm{Na}=43: 1$ ); treatment $\mathrm{C}: 30 \mathrm{~g} \mathrm{~K}$ and $2.7 \mathrm{~g} \mathrm{NA} / \mathrm{kg}$ DM (high $\mathrm{K}$-and Na-supply, $\mathrm{K}: \mathrm{Na}=11: 1$ ). At the beginning of the trial (pre-period) as well as from the $32^{\text {nd }}$ to the $42^{\text {nd }}$ day (main period) a balance period with faeces- and urine-sampling took place.

A negative influence of the high $\mathrm{K}$-supply in diets $\mathrm{B}$ and $\mathrm{C}$ on the $\mathrm{Mg}$-metabolism was already observed in the pre-period. Moreover, animals with high $\mathrm{K}$ - and Na-supply (treatment $\mathrm{C}$ ) showed an absolute and relative increase in Na-excretion in the urine. However except for the first balance day, the Na-urine excretion of treatment B (high K-supply and correct Na-intake) corresponded to that of treatment A.

Confirmed by the results of the main period, the negative influence of high K-levels on $\mathrm{Mg}$ metabolism of cattle and sheep was also found in goats. Besides the apparent Mg-digestibility which tended to be lower (A: $38 \% ; \mathrm{B}: 33 \% ; \mathrm{C}: 30 \%)$ the animals fed diets $\mathrm{B}$ and $\mathrm{C}$ also exhibited significantly lower Mg-retention (A: $0 \mathrm{~g} ; \mathrm{B}:-0.09 \mathrm{~g}$ and $\mathrm{C}:-0.11 \mathrm{~g} / \mathrm{animal}$ per day ; $\mathrm{P}<1 \%$ ). The extreme $\mathrm{K}$-supply and the simultaneous wide $\mathrm{K}: \mathrm{Na}$ ratio in diet $\mathrm{B}$ did not lead to an increased $\mathrm{Na}$-excretion as it is sometimes reported in the literature. Concerning $\mathrm{Na}$ excretion, there was no statistical difference $(P>5 \%)$ between treatments $A$ and $B$. The same applies to Na-retention (A : $-0.54 \mathrm{~g}$ and $-0.43 \mathrm{~g} /$ animal per day respectively in $\mathrm{B}$ ). However, with a Na-retention of $-1.57 \mathrm{~g} / \mathrm{animal}$ per day there was a significant difference $(\mathrm{P}<1 \%)$ between the animals of treatment $\mathrm{C}$ (high $\mathrm{K}$ - and Na-supply with correct $\mathrm{K}$ : $\mathrm{Na}$ ratio) and the remaining treatments.

In the milk, the content of $\mathrm{Mg}(\mathrm{A}: 0.14 \mathrm{~g} ; \mathrm{B}: 0.14 \mathrm{~g} ; \mathrm{C}: 0.13 \mathrm{~g} / \mathrm{kg}$ milk), of $\mathrm{K}$ (A : $2.05 \mathrm{~g} ; \mathrm{B}: 2.12 \mathrm{~g} ; \mathrm{C}: 2.11 \mathrm{~g} / \mathrm{kg}$ milk) and of Na $(\mathrm{A}: 0.42 \mathrm{~g} ; \mathrm{B}: 0.43 \mathrm{~g} ; \mathrm{C}: 0.42 \mathrm{~g} / \mathrm{kg}$ milk) were not influenced by the varying supply of $\mathrm{K}$ and $\mathrm{Na}(\mathrm{P}>5 \%)$. The same applies to the serum values for $\mathrm{Mg}(\mathrm{A}: 1.11 \mathrm{mmol} ; \mathrm{B}: 1.05 \mathrm{mmol} ; \mathrm{C}: 1.07 \mathrm{mmol} / \mathrm{l}$ serum $), \mathrm{K}(\mathrm{A}: 4.05 \mathrm{mmol} ; \mathrm{B}$ : $3.916 \mathrm{mmol} ; \mathrm{C}: 4.66 \mathrm{mmol} / \mathrm{l}$ serum) and $\mathrm{Na}(\mathrm{A}: 147 \mathrm{mmol} ; \mathrm{B}: 149 \mathrm{mmol} ; \mathrm{C}: 149 \mathrm{mmol} / \mathrm{l}$ serum). There were, however, highly significant differences $(P<5 \%)$ in the course of the day. The stability of the $\mathrm{K}$ - and Na-serum values in the trial clearly showed that they are not - as in other ruminants - suitable indicators for the estimation of the supply in the urine that might give more information on Na-intake, as there was a correlation of $-0.87(\mathrm{P}<1 \%)$ between Naintake and this ratio in the present experiment.

Key words: Potassium, sodium, magnesium, goat.

\title{
Variations in the in sacco by product degradation in goats
}

\author{
P. CHAPOUTOT, D. SAUVANT \\ Station de Nutrition et Alimentation (INRA), Institut national agronomique Paris-Grignon, \\ 16, rue Claude-Bernard, 75231 Paris Cedex 05
}

A total of 18 current agro-industrial by-products were studied in goats with a standardized « in sacco " procedure : wheat bran (WBR), corn glutenfeed (CGF), brewer's grains (BWG), wheat distiller's grains (WDG), groundnut meal (GNM), maize germ meal (MGM), coconut meal (CCM), palmkernel meal (PKM), soyabean hulls (SBH), sunflower hulls (SFH), sugar beet pulp (BTP), citrus pulp (CIP), pea by-products (PBP), spinach by-products (SPI), tomato pulp (TOP), grape pulp (GRP), grape kernel (GRK), dehydrated lucerne (DLU). 
The mean dry matter degradation after 48 hours (DMD 48), largely varied between feeds: $29.3 \%<\mathrm{DMD} 48<96.4 \%$ (SFH, GRK, GRP = from 29 to $45 \%$; BWG, TOP, DLU, WBR $=$ from 65 to $75 \%$; CCM, PKM, WDG, GNM, CGF, PBP, MGM = from 83 to $90 \%$; SPI, SBM, BTP, CIP > $90 \%$ ).

These values were used to estimate the « in vivo » organic matter digestibility with a specific prediction equation obtained from «in vivo" experimental data of the laboratory with 17 concentrates or by-products for ruminants. This procedure allowed to confirm largely the OMD values of some by-products already present in the 1978 INRA table; moreover it permitted to obtain reliable estimations of the OMD values of unknown by-products.

The Acid Detergent Lignin (ADL) content is the analytical parameter which is the most related to the by-product DMD $48:$ DMD $48=88.3-1.25$ ADL $(R=-0.85, \operatorname{RSD}=10.7)$.

Several by-products having a similar DMD 48 value (CIP $=96.4 \%$, BTP $=92.9 \%$ and $\mathrm{SBH}=92.5 \%$; Or PBP $=87.8 \%, \mathrm{GNM}=86.1 \%, \mathrm{MGM}=89.8 \%$ and $\mathrm{CCM}=83.2 \%)$ presented very different levels of dry matter degradation after 12 hours (DMD 12) (CIP $=83.7 \%$ vs $\mathrm{BTP}=74.2 \%$ and $\mathrm{SBH}=52.9 \% ; \mathrm{PBP}=80.6 \%$ and $\mathrm{GNM}=79.7 \%$ vs $\mathrm{MGM}=59.7 \%$ and $\mathrm{CCM}=56.7 \%$ ).

These differences are explained by the large variations in dry matter degradation rate (DMDR) values between 0 and 6 hours (SBH, GRP, GRK, BWG $=$ from 3 to $4.5 \% \mathrm{~h}^{-1} ; \mathrm{PKM}$, CCM, SBH, MGM, CGF, BTP, DLU, TOP = from 5.5 to $7.5 \% \mathrm{~h}^{-1}$; SPI, WDG, WBR, CIP, PBP, GNM $=$ from 8.5 to $11.5 \% \mathrm{~h}^{-1}$ ) and the lack of relationship between the DMD 48 and DMDR values of the feeds.

This latter parameter is more precisely related to the dietary Neutral Detergent Fiber (NDF) content during the first phase of incubation for instance between 0 and 6 hours: DMDR $(0-6)=14.4-0.14$ NDF $(\mathrm{R}=-0.94, \mathrm{RSD}=0.9)$.

This study allowed to obtain data of general interest for ruminants and, on the other hand, useful references in dairy goat feeding.

Key words : By-products, goat, in sacco degradability.

\title{
Digestibility of Atriplex nummularia and Aacacia salicina in goats
}

\author{
J. SILVA-COLOMER *, E. MOLINA, J. FONOLLÁ, J, BOZA \\ Departamento de Fisiología Animal, Estación Experimental del Zaidín (C.S.I.C.), \\ Profesor Albareda, I, 18008 Granada (Spain) \\ * I.A.D.I.Z.A.-C.O.N.I.C.E.T., Mendoza (Argentina).
}

In rangelands of arid areas, browses of shrubs and trees make an important contribution to animal feeding when herbaceous forage is scarce. In this research work the nutritive value of two interesting woody species : Atriplex nummularia (Dry matter, DM : $34.4 \%$; organic matter, OM : $77.4 \%$, acid detergent fibre, ADF : $28.5 \%$, crude protein, CP : $17.0 \%$ ) and Acacia salicina (DM : $32.8 \%$; OM : $83.3 \%$; ADF : $24.5 \%$; CP : $17.3 \%$ ) was studied.

Six Granadina goats were used to determine digestibility « in vivo ». Animals were fed at about a maintenance level a basal diet including pelleted lucerne hay, barley, sunflower cake and a mineral corrector, and a test diet based on equal parts $(50 / 50 \mathrm{DM})$ of the basal diet and Atriplex nummularia or Acacia salicina. They were pre-cutted and oven dried at $70^{\circ} \mathrm{C}$ and then stabilized at environment temperature. The trials of "in vivo " digestibility lasted twenty two days (fifteen days of adaptation to feeding and seven days of faeces collection). Digestibility of Atriplex nummularia and Acacia salicina was obtained by difference. The digestibility " in vitro » was determined following TiLLEY and TERRY's techniques (1963), with ruminal fistulated goats which were fed the basal diet. The solubility with cellulase from Trichoderma viride was obtained according to Aufrere's procedure (1982). We have obtained a simple regression equation from 